\title{
MORTALITY AND RISKS RELATED TO HEALTHCARE-ASSOCIATED INFECTION
}

\author{
Ester Sena Souza ${ }^{1}$, Renata Aparecida Belei², Claudia Maria Dantas de Maio Carrilho ${ }^{3}$, Tiemi Matsuo ${ }^{4}$ \\ Sueli Fumie Yamada-Ogatta ${ }^{5}$, Galdino Andrade 6 , Marcia Regina Eches Perugini ${ }^{7}$, Flávia Meneguetti Pieri ${ }^{8}$, \\ Elma Mathias Dessunti ${ }^{9}$, Gilselena Kerbauy ${ }^{10}$
}

1 Resident nurse at the Surgical-Medical Nursing Program of the Universidade Estadual de Londrina (UEL). Londrina, Paraná, Brazil. E-mail: estersenas@hotmail.com

2 Ph.D. in Education. Nurse at the University Hospital of Londrina. Londrina, Paraná, Brazil. E-mail: rabelei@yahoo.com.br

${ }^{3}$ Doctoral student in Parasitic and Infectious Diseases. Doctor at the Hospital Univeritário de Londrina. Londrina, Paraná, Brazil. E-mail: claudiacarrilho@sercomtel.com.br

4 Ph.D. in Statistics. Professor at the Statistics Department of UEL. Londrina, Paraná, Brazil. E-mail: tiemi.matsuo@gmail.com

${ }^{5}$ Ph.D. in Molecular Biology. Professor at the Microbiology Department of UEL. Londrina, Paraná, Brazil. E-mail: ogatta@ uel.br

${ }^{6}$ Ph.D. in Microbial Ecology. Professor at the Microbiology Department of UEL. Londrina, Paraná, Brazil. E-mail: andradeg@ uel.br

7 Ph.D. in Microbiology. Professor at the Pathology, Clinical and Toxicological Analysis Department of UEL. Londrina, Paraná, Brazil. E-mail: marciaperugini@hotmail.com

8 Ph.D in Nursing. Professor at the Nursing Department of UEL. Londrina, Paraná, Brazil. E-mail: fpieri@uel.br

${ }_{9}$ Ph.D. in Public Health. Professor at the Nursing Department of UEL. Londrina, Paraná, Brazil. E-mail: elma@sercomtel. com.br

${ }^{10}$ Ph.D. in Microbiology. Professor at the Nursing Department of UEL. Londrina, Paraná, Brazil. E-mail: gilselena@uel.br

\begin{abstract}
Healthcare-associated infections are a major cause of morbidity-mortality among hospitalized patients. The aim of this epidemiological study was to determine mortality and risks related to death in adult patients with healthcare-associated infections admitted to a teaching hospital in one year. Patient data were collected from infection medical reports. The mortality rate associated with infections was $38.4 \%$, and it was classified as a contributing factor to deaths in $87.1 \%$ of death cases. The correlation between healthcare-associated infection and death was statistically significant among clinical patients $(41.3 \%)$ presenting comorbidities related to the diagnosis $(55.8 \%)$, cardiovascular infection $(62.2 \%)$, pneumonia $(48.9 \%)$, developing sepsis $(69.0 \%)$, as well as patients who had been colonized $(45.2 \%)$ and infected $(44.7 \%)$ by multidrug resistance microorganisms.
\end{abstract}

DESCRIPTORS: Cross infection. Epidemiology. Mortality. Risk factors.

\section{MORTALIDADE E RISCOS ASSOCIADOS A INFECÇÃO RELACIONADA À ASSISTÊNCIA À SAÚDE}

RESUMO: A infecção relacionada à assistência à saúde é uma das principais causas de morbimortalidade entre pacientes hospitalizados. O objetivo deste estudo epidemiológico foi determinar a mortalidade e os riscos associados ao óbito de pacientes adultos com infecção relacionada à assistência à saúde, internados em um hospital-escola no período de um ano. Dados dos pacientes foram coletados das fichas de notificação de infecções. A taxa de mortalidade associada a essas infecções foi de $38,4 \%$, classificadas como fator contribuinte em $87,1 \%$ dos óbitos. A associação das infecções relacionadas à assistência à saúde com o óbito foi estatisticamente significativa entre pacientes clínicos $(41,3 \%)$, que apresentavam comorbidades associadas ao diagnóstico (55,8\%), com infecção cardiovascular (62,2\%), pneumonia $(48,9 \%)$, que evoluíram com sepse $(69,0 \%)$, colonizados $(45,2 \%)$ ou infectados $(44,7 \%)$ por microrganismos multirresistentes. Concluiu-se que as infecções contribuíram para o óbito da maioria dos pacientes.

DESCRITORES: Infecção hospitalar. Epidemiologia. Mortalidade. Fatores de risco. 


\title{
MORTALIDAD Y RIESGOS ASOCIADOS A LA INFECCIÓN RELACIONADA CON LA ASISTENCIA A LA SALUD
}

\begin{abstract}
RESUMEN: La infección relacionada con la atención sanitaria es una de las principales causas de morbimortalidad entre los pacientes hospitalizados. El objetivo de este estudio epidemiológico fue determinar la mortalidad y los riesgos asociados con el fallecimiento de pacientes adultos con la infección relacionada con la atención sanitaria ingresados en un hospital universitario en el periodo de un año. Los datos de los pacientes se obtuvieron de registros de notificación de infecciones. La tasa de mortalidad asociada con las infecciones fue del $38,4 \%$, y fueron clasificados como un factor que contribuye en el 87,1\% de las muertes. La asociación de la infección relacionada con la atención sanitaria con el fallecimiento fue estadísticamente significativa entre pacientes clínicos $(41,3 \%)$, que presentaron comorbilidad asociadas a el diagnóstico $(55,8 \%)$, con infección cardiovascular $(62,2 \%)$, neumonía $(48,9 \%)$, que desarrollaron sepsis $(69,0 \%)$, colonizados $(45,2 \%)$ o infectados $(44,7 \%)$ por microorganismos multirresistentes. Se concluyó que las infecciones contribuyeron a la muerte de la mayoría de los pacientes
\end{abstract}

DESCRIPTORES: Infección hospitalaria. Epidemiología. Mortalidad. Factores de riesgo.

\section{INTRODUCTION}

Healthcare-associated infections (HAI) stand out as one of the major causes of morbidity-mortality concerning patients who undergo clinical procedures. These infections are deemed to be a relevant healthcare challenge generating high rates of health complications, extension of hospital stay, direct enhancement of healthcare costs. Additionally, HAI favor the selection and dissemination of multidrug resistance microorganisms. ${ }^{1-2}$

The Centers for Disease Control and Prevention (CDC) define HAI as a localized or systemic condition resulting from an adverse reaction to the presence of an infectious agent acquired after the patient's admission to the healthcare service. ${ }^{3}$ In Brazil, Ordinance 2,616 from the Ministry of Health considers HAI as a significant risk to the health of patients in the services, and defines them as any infection acquired after the admission of the patient to the healthcare service manifested either 48 hours following hospitalization or prior to such period whenever it is correlated with invasive procedures. Healthcare-associated infections may also manifest after the patient's discharge whenever it is associated with surgeries or invasive procedures carried out at healthcare services. ${ }^{4}$

The high mortality risk associated with HAI is intrinsically connected with factors such as the performance of diagnostic and therapeutic invasive procedures, ${ }^{5}$ the severity of the patient's base disease, ${ }^{6}$ the location of the infection, ${ }^{7}$ the inadequacy of the therapy, and the sensitivity of microorganisms to antimicrobials. ${ }^{8}$

A North American multicentric study showed that nearly 1.7 million annual cases of HAI are observed in the US, and approximately 99,000 yearly deaths are associated with the occurrence of these infections in the country. ${ }^{9}$ An European study concluded that HAI affect one out of 10 hos- pitalized patients and cause nearly 5,000 annual deaths in the continent. ${ }^{10}$

In Brazil, data related to HAI are still poorly documented due to the reduced consolidation of information on the part of several hospitals, thus making it very difficult for healthcare professionals to come up with a set of knowledge on the extension of the problem in the country. The Ministry of Health assessed the magnitude of hospital infections in 99 outsourced hospitals covered by the Unified Health System (SUS), and located in Brazilian capitals, identifying a HAI rate of $13.0 \%$ among hospitalized patients. ${ }^{11}$

Bearing in mind the complexity and severity of HAI, demonstrated by the high mortality rates found, the need for a deeper approach regarding the prevention and control of infections as a patient's safety promotion strategy $\mathrm{y}^{12}$ and the direct contribution of the nursing practice to the control of this type of infection, the aim of the present study was to determine mortality rates and risks associated to the death of adult patients with HAI admitted to a teaching hospital.

\section{METHOD}

This descriptive, retrospective epidemiologic study, whose sample was comprised of all medical condition notification forms and medical reports of adult patients (aged 18+) diagnosed with HAI, was carried out between December 2009 and January 2011, in compliance with the criteria established by the Centers for Disease Control and Prevention/National Healthcare Safety Network (CDC) $\mathrm{NHSN})^{3}$ and the admission criteria of the University Hospital (UH). The University Hospital of Londrina stands out as a supplementary organ of the State University of Londrina (UEL), a reference center for the SUS in the Northern region of the state of Paraná, Brazil. The hospital counts on 316 beds 
distributed among hospitalization units, emergency unit and intensive care unit (ICU). The wards addressed by this study were as follows: emergency unit, nursing departments (male, female, tuberculosis and transmissible diseases), maternity, burn care center (BCC), bone marrow transplant center and adult intensive care unit (ICU 1 - post-surgery patients; ICU 2 - chronic patients).

Data were gathered from the patients' medical reports and medical condition notification forms regarding HAI, and formulated in compliance with the criteria established by the North American infection surveillance system, the National Nosocomial Infection Surveillance (NNIS), ${ }^{13}$ filled out and analyzed by the multiprofessional team of the Hospital Infection Control Commission $(\mathrm{CCIH})$ of the UH-UEL in all cases of HAI.

The gathered variables included outcome (discharge and death), gender, age, ward and length of stay, treatment classification (clinical and surgical), presence of comorbidities (Charlson Comorbidity Index-CCI), ${ }^{14}$ major location of the infection, development of sepsis, invasive procedures carried out, microorganisms isolated in cultures, and sensitivity profile against antimicrobials.

The correlation between death and HAI was classified as: 1) death related to HAI; 2 ) death not related to HAI; or 3 ) undefined correlation between death and HAI. This classification standard was determined by medical criteria and grounded on preset concepts advocated by the CDC, which take into account the patient's whole clinical context. As for the development of sepsis, such complication was classified as sepsis, severe sepsis, and septic shock, in compliance with the criteria set forth by the American College of Chest Physicians/Society of Critical Care Medicine (ACCP/SCCM).$^{15}$

Regarding the etiological agent, data were extracted from lab reports provided by the institution's computer system. Lab identification and the sensitivity profile of microorganisms against antimicrobials complied with the criteria established by the Clinical and Laboratory Standard Institute (CLSI). ${ }^{16}$ The classification of such microorganisms concerning colonization or infection processes complied with the criteria established by the CDC/ NHSN. ${ }^{3}$ As for the classification of the multidrug resistance to antimicrobials, the criteria set forth by the CDC were complied with. ${ }^{17}$

Multidrug resistant microorganisms were classified as follows: Acinetobacter baumannii and Pseudomonas sp, resistant to carbapenemics; Klebsiella pneumonial and Escherichia coli, resistant to either carbapenems or cephalosporines (third or fourth generation) or monobactamics; coagulase-negative Staphylococcus and Staphylococcus aureus resistant to oxacilin; Enterobacter sp, other enterobacteria and Serratia sp, resistant to carbapenem or cephalosporine (fourth generation); Enterococcus sp, resistant to vancomycin and Streptococcus sp, resistant to penicilin, cefotaxime, levofloxacine, meropenem, glycopeptide and macrolides; Burkholderia cepacia, Stenotrophomonas sp and Moraxella sp were grouped as non-fermenting and all of them were considered as multidrug resistant microorganisms as a result of their intrinsic resistance to various antibiotics. ${ }^{17}$

Data tabulation and analysis were carried out using the Statistical Package for the Social Sciences (SPSS) software, version 19. Categorical variables were assessed as simple and relative frequencies and shown in tables. For continuous variables, the study applied the central and dispersion tendency measurements (mean, median and standard deviation). In order to assess the correlation of the variables with the hospital infection, the authors employed a bivariate analysis by means of Pearson's Chi-Square Test $\left(\mathrm{X}^{2}\right)$ or Fisher's exact Test. Relative risk and confidence intervals of 95\% (CI 95\%) were used as force measurements for the correlations. The adopted level of significance was $5 \%(p \leq 0.05)$.

The research proposal was approved by the Human Research Ethics Committee of the State University of Londrina, receiving the Ethics Appreciation Certificate (CAAE) under protocol number 0015.0.268.000-11.

\section{RESULTS AND DISCUSSION}

Throughout the period of the study, 11,177 adult patients were hospitalized at the UH-UEL. From these, $889(8.0 \%)$ were diagnosed with at least one episode of HAI, from which 341 evolved to death, thus reflecting a mortality rate of $38.4 \%$. Other studies found lower rates, namely $11.0 \%, 18$ $12.8 \%{ }^{19}$ and $16.8 \% .^{7}$

In the present study, the majority of deaths $(87.1 \%)$ among the patients that showed HAI was related to these infections, thus generating a significant statistical association $(p<0.001)$. A study carried out for one year in a French university hospital indicated that the infections were considered the major cause of deaths in $4.4 \%$ of patients with HAI. Concurrently, the infection was deemed to be a contributing factor toward death in $37.8 \%$ of patients. ${ }^{18}$ Table 1 depicts the characteristics of the patients with HAI who evolved to death. 
Table 1 - Relative death frequency, percentage and risk among patients with HAI $(n=889)$ who evolved to death $(n=341)$ according to sociodemographic and clinical variables. Londrina, Paraná, 2012

\begin{tabular}{|c|c|c|c|c|c|c|c|}
\hline \multirow{3}{*}{$\begin{array}{l}\text { Variables } \\
\text { Sex }\end{array}$} & \multirow{3}{*}{ Total } & \multicolumn{2}{|c|}{ Death } & \multirow{2}{*}{ p value } & \multirow{2}{*}{$\mathbf{R}^{*}$} & \multirow{2}{*}{\multicolumn{2}{|c|}{ CI 95\% ${ }^{\dagger}$}} \\
\hline & & \multirow[t]{2}{*}{$\mathbf{n}$} & \multirow[t]{2}{*}{$\%$} & & & & \\
\hline & & & & \multirow{3}{*}{0.015} & \multirow{3}{*}{1.26} & \multirow{3}{*}{1.04} & \multirow{3}{*}{1.53} \\
\hline Male & 601 & 247 & 41.1 & & & & \\
\hline Female & 288 & 94 & 32.6 & & & & \\
\hline \multicolumn{8}{|l|}{ Group age } \\
\hline $18-34$ & 156 & 27 & 17.3 & \multirow[t]{5}{*}{$<0.001$} & & & \\
\hline $35-49$ & 177 & 63 & 35.6 & & & & \\
\hline $50-64$ & 203 & 83 & 40.9 & & & & \\
\hline $65-79$ & 226 & 89 & 39.4 & & & & \\
\hline$\geq 80$ & 127 & 79 & 62.2 & & & & \\
\hline \multicolumn{8}{|l|}{ Length of stay } \\
\hline Up to 15 days & 299 & 112 & 37.5 & \multirow[t]{5}{*}{0.908} & & & \\
\hline From 16 to 30 days & 334 & 133 & 39.8 & & & & \\
\hline From 31 to 45 days & 129 & 49 & 38.0 & & & & \\
\hline From 46 to 60 days & 73 & 27 & 37.0 & & & & \\
\hline$>60$ days & 54 & 20 & 37.0 & & & & \\
\hline \multicolumn{8}{|l|}{ Type of patient } \\
\hline Clinical & 766 & 316 & 41.3 & \multirow[t]{2}{*}{$<0.001$} & \multirow[t]{2}{*}{2.03} & \multirow[t]{2}{*}{1.42} & \multirow[t]{2}{*}{2.91} \\
\hline Surgical & 123 & 25 & 20.3 & & & & \\
\hline \multicolumn{8}{|l|}{ Comorbidities } \\
\hline Yes & 387 & 216 & 55.8 & \multirow[t]{2}{*}{$<0.001$} & \multirow[t]{2}{*}{2,24} & \multirow[t]{2}{*}{1,88} & 2,67 \\
\hline No & 502 & 125 & 24.9 & & & & \\
\hline Site of infection & & & & & & & \\
\hline Cardiovascular & 45 & 28 & 62.2 & $<0.001$ & 1.68 & 1.31 & 2.14 \\
\hline Pneumonia & 619 & 303 & 48.9 & $<0.001$ & 3.48 & 2.56 & 4.72 \\
\hline Blood stream & 31 & 13 & 41.9 & 0.677 & 1.10 & 0.72 & 1.67 \\
\hline Urinary tract & 276 & 108 & 39.1 & 0.751 & 1.03 & 0.86 & 1.23 \\
\hline Skin and subcutaneous & 43 & 10 & 23.3 & 0.037 & 0.59 & 0.34 & 1.03 \\
\hline Operation room & 115 & 20 & 17.4 & $<0.001$ & 0.42 & 0.28 & 0.63 \\
\hline Others & 12 & 4 & 33.3 & 1.000 & 0.87 & 0.39 & 1.94 \\
\hline Sepsis & & & & & & & \\
\hline Yes & 413 & 285 & 69.0 & $<0.001$ & 5.87 & 4.55 & 7.56 \\
\hline No & 476 & 56 & 11.8 & & & & \\
\hline Invasive procedures & & & & & & & \\
\hline Tracheotomy & 14 & 11 & 78.6 & 0.002 & 2.08 & 1.56 & 2.77 \\
\hline Orotracheal tube & 386 & 261 & 67.6 & $<0.001$ & 4.25 & 3.44 & 5.26 \\
\hline Central venous catheter & 117 & 65 & 55.6 & $<0.001$ & 1.55 & 1.29 & 1.87 \\
\hline Vesical probe & 356 & 188 & 52.8 & $<0.001$ & 1.84 & 1.56 & 1.17 \\
\hline Drains & 40 & 13 & 32.5 & 0.436 & 0.84 & 0.53 & 1.33 \\
\hline
\end{tabular}

"RR: relative risk; ${ }^{\dagger} \mathrm{CI}$ : confidence interval.

According to Table 1, there was a statistical association related to the HAI among men (41.1\%). [A long list of factors contributes to the development of HAI. Among them, those specifically related to exposed patients, especially those in advanced age, stand out. ${ }^{7}$ In the present study, the mean age of patients was 56.97 years (18-98 age range) and the major prevalence of infections was observed in individuals aged 50 years or over (62.5\%). A similar finding was observed in relation to mortality rates, where $62.2 \%$ of deaths related to older individuals $(\mathrm{p}<0.001)$ stood out, according to table 1.

Another factor that collaborates to the occurrence of HAI is the prolonged hospital stay..$^{19}$ In the present study, the mean length of hospital stay of patients with HAI was 27.2 days and most of the individuals $(66.4 \%)$ remained in the hospital for a period longer than 15 days. Among the deaths, the mean length of hospital stay varied from $37.0 \%$, for periods higher than 60 days, to $39.8 \%$, for $16-30$ 
days, and did not show any significant statistical association. Accordingly, a retrospective study that identified 133 deaths associated with HAI in a Brazilian outsourced hospital in a period of one year showed a mean length of hospital stay of 35 days and a maximum of 236 days. ${ }^{20}$

As for the hospitalization departments, critical units presented higher HAI rates, namely the BCC (98.2\%), ICU 2 (48.7\%) and ICU 1 (24.8\%) when compared with the nursing ward $(7.9 \%)$ and the emergency unit $(4.6 \%)$. Consequently, a higher mortality percentage among patients with HAI was also observed in these units, ICUs $(93.8 \%)$ and BCC (77.8\%). Studies highlight that the highest mortality rates among patients with HAI are correlated to the hospitalization in ICUs. ${ }^{9,21}$ Taking into account that these wards handle the hospital's most severe cases, high mortality rates are quite comprehensible. Additionally, patients at these wards are more exposed to infections as a result of the severity and diversity of invasive procedures often carried out there.

A prevalence of clinical diagnoses among patients with HAI $(86.2 \%)$ was observed in comparison with surgical diagnoses (13.8\%). Mortality was twice as high among clinical patients $(p<0.001)$ undergoing the risk of evolving to death in comparison with surgical cases (Table 1). Similarly, a North American study carried out for eight months in an ICU of an outsourced hospital identified that $60.3 \%$ of patients with HAI were hospitalized as a result of clinical diagnosis, whereas $39.7 \%$ were submitted to surgical procedures. ${ }^{8} \mathrm{~A}$ study performed in ICUs in Greece for a period of 11 months revealed that among the 152 patients with HAI, $67.1 \%$ were clinical patients and $32.9 \%$ were surgical patients. ${ }^{22}$

Literature data highlight that the clinical conditions and the presence of comorbidities in the moment of admission to the hospital represent relevant risk factors for death among patients with HAI. ${ }^{23-24}$ Another study indicates the occurrence of higher mortality rates associated with HAI and observes a special correlation between death rates and the presence of risk factors, such as chronic diseases, immunosuppression, and neoplasia. ${ }^{24}$

The analysis of pathologies associated with the HAI diagnosis in the present study allowed for the identification of a high frequency of comorbidities $(43.5 \%)$ among patients with HAI, with cerebrovascular diseases $(20.4 \%)$, congestive cardiac insufficiency $(11.6 \%)$ and neoplasias (11.6\%) being the most prevalent comorbidities. However, other comorbidities showed stronger impact in the mortality of patients with HAI. Among 13 patients with metastatic tumors associated with an infectious status, $84.6 \%$ evolved to death. When the infection was observed in patients with chronic liver disease (16), death reached $81.2 \%$ of cases. In patients with diabetes mellitus (25), $80 \%$ evolved to death. Mortality among patients with comorbidities was quite expressive (55.8\%, $\mathrm{p}<0.001$ ), with nearly twice as high risk of death when compared with patients who did not show any comorbidity (Table 1).

Similar data were observed in other studies. A study carried out in two university hospitals and involving 390 patients with HAI and sepsis identified a high mortality frequency among individuals presenting associated risk factors, such as metastatic disease $(93.6 \%)$, chronic diseases $(68.2 \%)$ and immunosuppression (55.2\%). ${ }^{24} \mathrm{Ad}-$ ditionally, an European study demonstrated that the most frequent comorbidities among patients with HAI, which evolved to death, were diabetes mellitus (27.8\%), neoplasias (27.8\%) and the malignant hematological disease $(22.2 \%){ }^{25}$

As for the data related to the location of the infection, 1,141 infection episodes were diagnosed among the 889 patients that participated in this study, being pneumonia $(54.3 \%)$, infection in the urinary tract $(24.2 \%)$ and infection at the operation room $(10.1 \%)$ the most frequent diagnoses. Infection of the cardiovascular system $(62.2 \%, \mathrm{p}<0.001)$, pneumonia $(48.9 \%, \mathrm{p}<0.001)$ and infection at the operation room $(17.4 \%, \mathrm{p}<0.001)$ presented significant statistical association. Mortality rates among patients with pneumonia were three times higher than those observed in patients who did not display such infection (Table 1 ).

A three-month long study carried out in hospitals in Belgium and involving 754 patients with HAI also revealed higher mortality rates among patients with infections in the respiratory tract $(23.7 \%)$. In the same study, infections in the blood stream responded for $15.0 \%$ of HAI that evolved to death; infections at the operation room reached $7.6 \%{ }^{19}$. Both frequencies are relatively lower than those observed in the present research.

Sepsis, the main complication of infections, affected $46.5 \%$ of patients with HAI. Its correlation with deaths was significant $(69.0 \%, \mathrm{p}<0.001)$ and increased up to six times the death risk for patients with such complication (Table 1). Figure 1 shows the distribution of patients in accordance with the classification of the sepsis. 


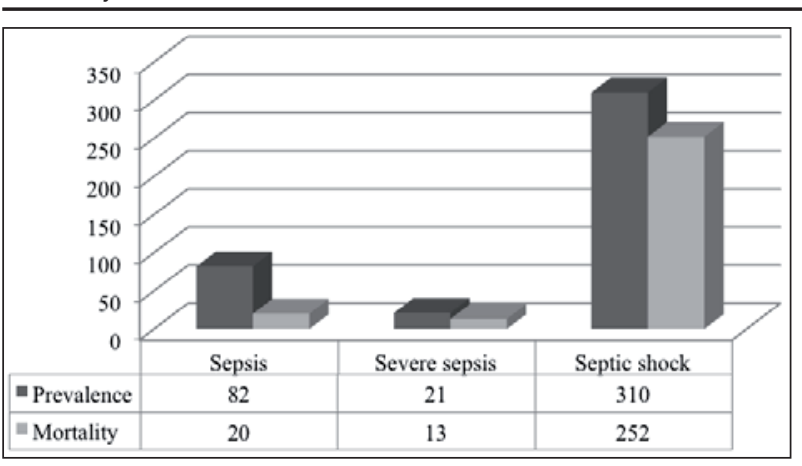

Figure 1 - Patients' prevalence and mortality rates, according to the sepsis classification. Londrina, Paraná, 2012

Among patients with sepsis, septic shock affected most of the individuals $(n=310,75.1 \%)$; data show that $81.3 \%$ of patients with septic shock, $61.9 \%$ of patients with severe sepsis, and $24.4 \%$ of those with sepsis died (Figure 1). [Unlike the above-mentioned data, a multicentric study involving 28 hospitals in Europe, Canada and Israel showed a lower frequency of sepsis among patients with HAI $(28.0 \%)$; septic shock also presented the most frequent evolution $(30.0 \%)$. The same study indicated that the mortality rate associated with sepsis varied from $44.8 \%$ to $67.9 \%$, and the rates related to septic shock ranged from $47.2 \%$ to $63.8 \%$; the highest percentages were observed in patients hospitalized in the ICUs of the healthcare centers involved in the study. ${ }^{21}$

The broad employment of invasive procedures in the hospital environment considerably enhances the risk level for HAI. Studies point out that, among infected patients, the performance of invasive procedures varied from $74.6 \%{ }^{26}$ to $93.0 \%$. These studies found lower percentages in comparison with those found in this study. The present study observed that invasive procedures were carried out in $57.9 \%$ (515) of patients with HAI, with some of them being submitted to more than one procedure. Over half of deaths $(55.0 \%)$ occurred in patients who had undergone invasive procedures, mainly tracheotomy and intubation, with frequency of $78.6 \%$ and $67.6 \%$, respectively. These procedures were significantly associated with death, thus enhancing in four and two times, respectively, the death risks for patients with HAI (Table 1).

Invasive procedures are more frequent in ICUs. A prospective study carried out in an ICU of a Brazilian outsourced hospital showed that all patients with HAI who evolved to death were submitted to at least one invasive procedure, being $100.0 \%$ submitted to delayed vesical catheteriza- tion, $93.3 \%$ employed central venous catheter, $80.0 \%$ were submitted to orotracheal intubation, and $46.6 \%$ were tracheotomized. ${ }^{27}$

As for the infections caused by invasive procedures, data show that mechanical ventilation was related to $30.7 \%$ of pneumonias; whereas urinary catheter was associated with $17.7 \%$ of the infections in the urinary tract. The study observed a statistical association for death risks in the pneumonia cases related to mechanical ventilation $[\operatorname{PAV}(68.5 \%, \mathrm{p}<0.001)]$ and infection of the urinary tract associated with the vesical catheter [CAUTI (49.0\%, $\mathrm{p}=0.002)]$.

A prospective study that investigated 1,731 cases of HAI in adults for three years pointed out the association between death and PAV $(81.6 \%)$ and death and CAUTI $(43.6 \%){ }^{28}$ nonetheless, the highest death frequency was observed in PAV cases when compared with the current study. Data related to infection of the blood stream associated with a catheter were not assessed in this study.

Still with regard to the PAV, it should be highlighted that the implementation of a series of nursing cautions would be quite relevant toward preventing and reducing infection rates and consequently the death frequencies associated to such infection. A qualitative study carried out in a public hospital in the Brazilian state of Santa Catarina addressed the collective construction of a PAV prevention bundle, and came up with a set of four critical cautions: oral hygiene with $0.12 \%$ chlorhexidine; headboard elevated at $30-45^{\circ}$; cuff pressure of 20-30 $\mathrm{cm} \mathrm{H} \mathrm{H}_{2} \mathrm{O}$; and special care with the aspiration of tracheal secretions. All of these measures generated strong proof regarding their effectiveness toward preventing the PAV, such as a high level of scientific evidence, application feasibility, and easy adherence. ${ }^{29}$

As for the microbiologic data, 2,784 microorganisms were separated from the positive cultures collected from the 889 patients with HAI. It was detected that $52.5 \%$ of these microorganisms were isolated from colonization processes; the remainder were isolated from infectious processes. In relation to the species of microorganisms, Klebsiella pneumoniae was the most prevalent microorganism both at the patient's discharge $(19.0 \%)$ and death $(21.2 \%)$ cases. The second most frequent microorganism in patients who evolved to death was Acinetobacter baumannii (18.5\%). Among discharged patients, the most frequent microorganism was Pseudomonas aeruginosa (11.3\%), according to Figure 2. 


\section{Coagulase-negative Staphylococcus}

Staphylococcus aureus

Serratia marcescens

Pseudomonas aeruginosa

Other enterobacteria

Nonfermenting

Klebsiella pneumoniae

Estreptococcus $s p$

Escherichia coli

Enterococcus sp

Enterobacter $s p$

Non-albicans Candida

Candida albicans

Acinetobacter baumannii

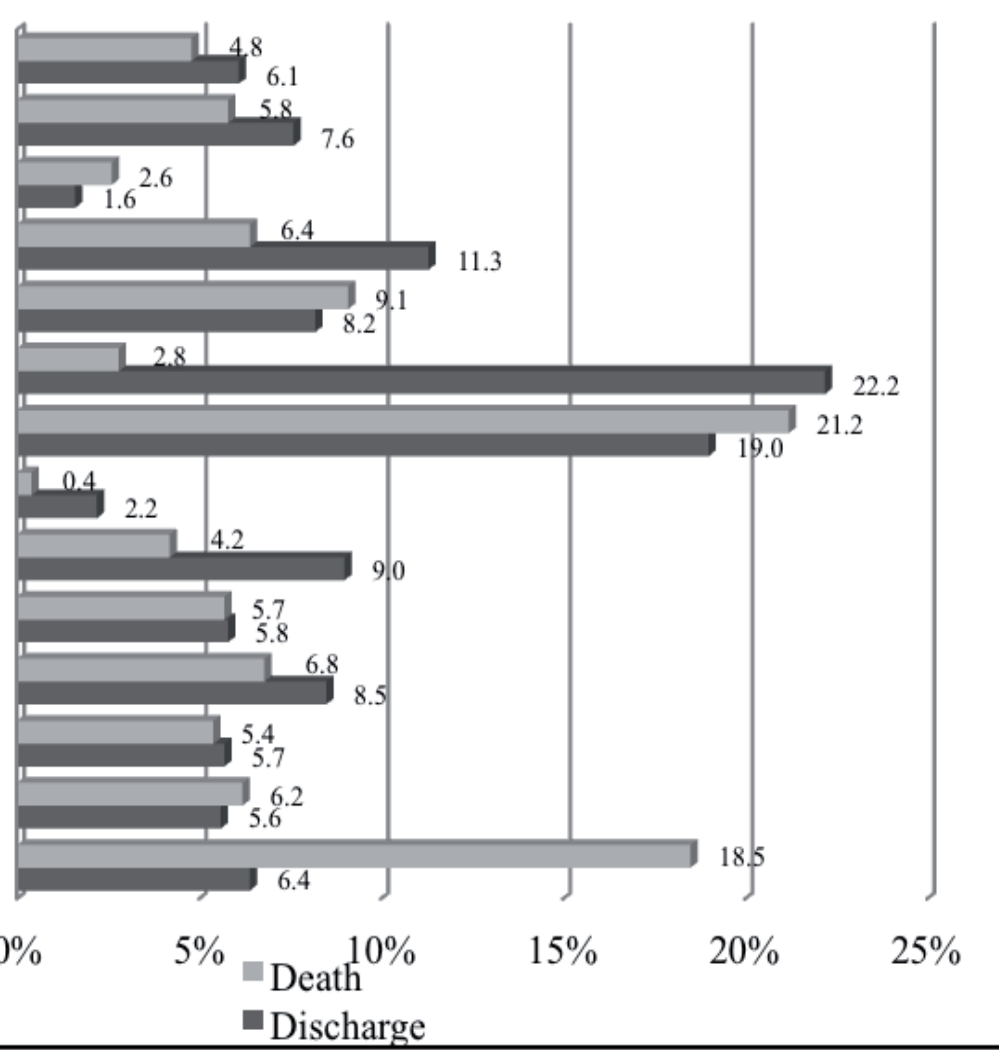

Figure 2 - Microorganisms according to the outcome of patients with healthcare-associated infections. Londrina, Paraná, 2012

In the present study, gram-negative bacteria stood out in the HAI epidemiology. Previous studies pointed out its remarkable relevance in mortality rates. Additionally, other studies show that the mortality rate caused by gram-negative bacteria is significantly higher in patients with HAI, ranging from $41.2 \%,{ }^{8}$ to $68.0 \% .{ }^{24}$

The antimicrobial resistance profile showed slight differences among patients with distinct outcomes. Almost half of patients with infections $(44.7 \%)$ or those colonized by multidrug resistant microorganisms (45.2\%) evolved to death. Among those who did not present multidrug resistance, the mortality rate was lower (33.0\% and $34.9 \%$, respectively), thus indicating a significant correlation between the multidrug resistance and the mortality rate among patients with HAI (Table 2).

Table 2 - Relative frequency, percentage and risk of death among patients with HAI who evolved to death $(n=341)$ according to the colonization and infection by multidrug resistant microorganisms. Londrina, Paraná, 2012

\begin{tabular}{|c|c|c|c|c|c|c|c|}
\hline \multirow{2}{*}{ Multidrug resistant microorganism } & \multirow{2}{*}{ Total } & \multicolumn{2}{|c|}{ Death } & \multirow{2}{*}{ p value } & \multirow{2}{*}{$\mathbf{R R}^{*}$} & \multirow{2}{*}{\multicolumn{2}{|c|}{ CI 95\% ${ }^{\dagger}$}} \\
\hline & & $\mathbf{n}$ & $\%$ & & & & \\
\hline Yes & 392 & 177 & 45.2 & $<0.001$ & 1.37 & 1.16 & 1.62 \\
\hline No & 497 & 164 & 33.0 & & & & \\
\hline \multicolumn{8}{|l|}{ Infecting } \\
\hline Yes & 318 & 142 & 44.7 & 0.004 & 1.28 & 1.09 & 1.51 \\
\hline No & 571 & 199 & 34.9 & & & & \\
\hline
\end{tabular}

${ }^{*} \mathrm{RR}$ : relative risk; ${ }^{\dagger} \mathrm{CI}$ : confidence interval. 
Infections caused by multidrug resistant bacteria represent a relevant public health challenge impacting several nations, and may become potential health and safety risks to patients. A North American study, based on NNIS and CDC data, associated multidrug resistant microorganisms with the elevation of death risks. ${ }^{30}$

A prospective study carried out in three ICUs in Greece between July 2009 and June 2010 showed a close correlation between multidrug resistant bacteria and deaths, indicating a mortality rate of $32.4 \%$, inferring a nearly twice as high death risk. ${ }^{22}$ Such risk was higher than the risk found in the present study, which varied between 1.28 and 1.37 among patients infected and colonized by multidrug resistant bacteria (Table 2).

\section{CONCLUSION}

The present study showed that the majority of deaths among patients with HAI was related with this type of infection, and that deaths were associated with comorbidities, patient's clinical status, performance of invasive procedures, pneumonia, cardiovascular system infection, sepsis, and multidrug resistant microorganisms. The factors that enhanced death risks among patients with HAI were: comorbidities, pneumonia associated or not with mechanical ventilation, orotracheal intubation, and tracheotomy.

In face of the results of the present study, and taking into account the high rates, complexity and severity of the HAI, the implementation of prevention strategies and efforts toward improving the care quality would be quite a relevant action. As such, specific epidemiological surveillance and case monitoring actions toward more improved treatment processes, as well as disclosure of data to the professionals involved in the institutional work process, employment of tools that allow for a more effective identification of patients at risk, strict control of care procedures, and immediate and adequate interventions, are critical steps in the hospital environment, tending to dramatically reduce the rates of these infections and consequently related deaths.

\section{REFERENCES}

1. Agência Nacional de Vigilância Sanitária (BR). Segurança do paciente e qualidade em serviços de saúde: medidas de prevenção de infecção relacionada à assistência à saúde. Brasília (DF): ANVISA; 2013.
2. El-Kholy A, Saied T, Gaber M, Younan MA, Haleim MMA, El-Sayed H, et al. Device-associated nosocomial infection rates in intensive care units at Cairo university hospitals: first step toward initiating surveillance programs in a resource-limited country. Am J Infect Control. 2012 Ago; 40(6):216-20.

3. Centers for Disease Control and Prevention (US): CDC/NHSN Surveillance Definitions for Specific Types of Infections. Atlanta (US): CDC; 2014.

4. Ministério da Saúde (BR). Portaria n. 2.616, de 12 de maio de 1998. Expede diretrizes e normas para a prevenção e o controle das infecções hospitalares. Brasília (DF): Diário Oficial da União, 13 Mai 1998. Seção 1

5. Garrouste-Orgeas M, Timsit JF, Tafflet M, Misset B, Zahar JR, Soufir L, et al. Excess risk of death from intensive care unit-acquired nosocomial bloodstream infections: a reappraisal. Clin Infect Dis. 2006 Abr; 42(8):1118-26.

6. Alexopoulos EC, Batzi E, Messolora F, Jelastopulu E. Wide range of point prevalence of healthcareassociated infections in Western Greece. Epidemiol Infect. 2011 Nov; 139(11):1734-9.

7. Avci M, Ozgenc O, Coskuner SA, Olut AI. Hospital acquired infections (HAI) in the elderly: comparison with the younger patients. Arch Gerontol Geriatr. 2012 Jan-Fev; 54(1):247-50.

8. Kollef MH, Sherman G, Ward S, Fraseret VJ. Inadequate antimicrobial treatment of infections: a risk factor for hospital mortality among critically ill patients. Chest. 1999 Fev; 115(2):462-74.

9. Klevens RM, Edwards JR, Richards CL, Horan TC, Gaynes RP, Pollock DA, et al. Estimating health careassociated infections and deaths in U.S. hospitals, 2002. Public Health Rep. 2007 Mar-Abr; 122(2):160-6.

10. Inweregbu K, Dave J, Pittard A. Nosocomial infections. Contin Educ Anaesth Crit Care Pain. 2005; 5(1):14-7.

11. Agência Nacional de Vigilância Sanitária (BR). Epidemiologia para o controle de infecção hospitalar. Caderno A. Brasília (DF): ANVISA; 2000. http:// www.cvs.saude.sp.gov.br/pdf/CIHCadernoA.pdf

12. Belela-Anacleto ASC, Sousa BC, Yoshikawa JM, Avelar AFM, Pedreira MLG. Higienização das mãos e a segurança do paciente: perspectiva de docentes e universitários. Texto Contexto Enferm. 2013 OutDez [acesso 2014 Abr 01]; 22(4):901-8. Disponível em: http://www.scielo.br/pdf/tce/v22n4/05.pdf

13. Emori TG, Culver DH, Horan TC, Jarvis WR, White JW, Olson DR et al. National nosocomial infections surveillance system (NNIS): description of surveillance methods. Am J Infect Contr. 1991 Fev; 19(1):19-35.

14. Charlson ME, Pompei P, Ales KL, MacKenzie R. A new method of classifying prognostic comorbidity in longitudinal studies: development and validation. J Chronic Dis. 1987; 40(5):373-83. 
15. American College of Chest Physicians, Society of Critical Care Medicine Consensus Conference: definitions for sepsis and organ failure and guidelines for the use of innovative therapies in sepsis. Crit Care Med. 1992 Jun; 20(6):864-74.

16. Institute for Drug Resistance. Clinical Laboratory Standards Institute antimicrobial susceptibility testing update. Wayne (US): CLSI; 2010.

17. Sievert DM, Ricks P, Edwards JR, Schneider A, Patel J, Srinivasan A, et al. Antimicrobial-resistant pathogens associated with heathcare-associated infections: summary of data reported to the National Heathcare safety Network at the Centers for Disease Control and Prevention, 2009-2010. Infect Control Hosp Epidemiol. 2013 Jan; 34(1):1-14.

18. Hautemanière A, Florentin A, Hartemann P, Hunter PR. Identifying possible deaths associated with nosocomial infection in a hospital by data mining. Am J Infect Control. 2011 Mar; 39(2):118-22.

19. Vrijens F, Hulstaert F, Devriese S, De Sande SV, et al. Hospital-acquired infections in Belgian acutecare hospitals: an estimation of their global impact on mortality, length of stay and healthcare costs. Epidemiol Infect. 2011 Jan; 140(1):126-36.

20. Guimarães AC, Donalisio MR, Santiago THR, Freire JB. Óbitos associados à infecção hospitalar, ocorridos em um hospital geral de Sumaré-SP, Brasil. Rev Bras Enferm. 2011 Set-Out; 64(5):864-9.

21. Alberti C, Brun-Buisson C, Burchardi H, Martin C, Goodman S, Artigas A, et al. Epidemiology of sepsis and infection in ICU patients from an international multicentre cohort study. Intensive Care Med. 2002 Fev; 28(2):108-21.

22. Apostolopoulou E, Raftopoulos V, Filntisis G, Kithreotis P, Stefanidis E, Galanis P, et al. Surveillance of device-associated infection rates and mortality in 3 Greek intensive care units. Am J Crit Care. 2013 Mai; 22(3):12-20.

23. Garrouste-Orgeas M, Timsit JF, Tafflet M, Misset B, Zahar JR, Soufir L, et al. Excess risk of death from intensive care unit-acquired nosocomial bloodstream infections: a reappraisal. Clin Infect Dis. 2006 Abr; 42(8):1118-26.

24. Khwannimit B, Bhurayanontachai R. The epidemiology of, and risk factors for, mortality from severe sepsis and septic shock in a tertiary-care university hospital setting. Epidemiol Infect. 2009 Set; 137(9):1333-41.

25. Tumbarello M, Repetto E, Trecarichi EM, Bernardini C, De Pascale G, Parisini A, et al. Multidrug-resistant Pseudomonas Aeruginosa bloodstream infections: risk factors and mortality. Epidemiol Infect. 2011 Nov; 139(11):1740-9.

26. Oliveira AC, Kovner CT, Silva RS. Infecção hospitalar em unidade de tratamento intensivo de um hospital universitário brasileiro. Rev Latino-am Enfermagem [online]. 2010 Mar-Abr [acesso 2013 Ago 15]; 18(2):8. Disponível em: http:/ / www.scielo. $\mathrm{br} / \mathrm{pdf} / \mathrm{rlae} / \mathrm{v} 18 \mathrm{n} 2 / \mathrm{pt} \_14 . \mathrm{pdf}$

27. Lima ME, Andrade D, Haas VJ. Avaliação prospectiva da ocorrência de infecção em pacientes críticos de unidade de terapia intensiva. Rev Bras Ter Intensiva. 2007 Jul-Set; 19(3):342-7.

28. Madani N, Rosenthal VD, Dendane T, Abidi K, Zeggwagh AA, Abouqal R. Health-care associated infections rates, length of stay, and bacterial resistance in an intensive care unit of Morocco: findings of the International Nosocomial Infection Control Consortium (INICC). Int Arch Med. [online] 2009 Oct [acesso 2013 Ago 15]; 2(1):2-29. Disponível em: http:/ / www.ncbi.nlm.nih.gov/pmc/articles/ PMC2765432/pdf/1755-7682-2-29.pdf

29. Silva SG, Nascimento ERP, Salles RK. Bundle de prevenção da pneumonia associada à ventilação mecânica: uma construção coletiva. Texto Contexto Enferm. 2012 Out-Dez [acesso 2013 Ago 15]; 21(4):837-44. Disponível em: http:/ / www.scielo.br/scielo.php?script $=\mathrm{sci}_{\text {_ }}$ arttext\&pid=S0104-07072012000400014

30. Kallen AJ, Mu Yi, Bulens S, Reingold A, Petit S, Gershman Ken, et al. Health care-associated invasive MRSA infections, 2005-2008. JAMA. 2010 Ago; 304(6):641-8. 